It also affords materials for the study of adaptation to the extreme conditions presented by the windblown dunes. The fauna, not less attractive, contains among other things many local varieties and species of invertebrates. As the author states: "It is the whole complex of plant and animal populations and the special conditions in which they live that give this place such high scientific value both for urgently needed research and for education, and indeed make it ugipue in its kind".

\section{Britaih's Contribution to the War Effort}

THE third and final report on Mutual Aid (Cmd. 6931. London : H.M. Stationery Office. 2d. net), with itg racof mutual aid from July 1, 1944, to the terapinon of the various agreements, and with its st ustifal report of mutual aid throughout the Whas has published opportunely. It is fitting that this record of the magnitude of the assistance which Great Britain gave to the United States, the U.S.S.R. and other allies, as well as received, should be made public now that fresh demands are being made to avert a possible collapse of Western Germany. At the height of the War, the United Nations were aiding each other freely on the scale of about $£ 4,500$ millions a year, and over the three years up to the end of the War, mutual aid was extended by the United Kingdom to fourteen countries, and totalled $£ 2,078,500,000$. Excluding oil obtained under LendLease, the value of supplies, services and capital received by the Allies amounted to 8 per cent of the national income of Great Britain and 16 per cent of her total war expenditure. The largest proportion of this-60 per cent-went to the United States, 15 per cent went to the U.S.S.R. and the remainder to European allies and China. The total value of reciprocal aid to the United States up to September 1, 1945 , is estimated at $£ 1,241,402,500$, and of this total 26 per cent took the form of servicing U.S. Forces, 18 per cent is accounted for by the cost of building capital ínstallations, the remainder being in respect of food, materials and equipment. More than half the services provided to American Forces is accounted for by shipping services.

In 1943, reciprocal aid was extended to include raw materials and foodstuffs, and from June 1943 until the end of the War, raw materials to the value of $£ 31,351,000$, two thirds of which was rubber, chiefly from Ceylon, were shipped from British Colonies to the United. States on United Kingdom account. A total of 615,000 tons of bulk foodstuffs was also exported from the Colonies to the United States under reciprocal aid. Mutual aid to the U.S.S.R. totalled $£ 318$ million, of which motor transport $(£ 118,856,000)$ and aircraft $(£ 128,893,000)$ were the largest items. Mutual aid figures for other countries are less complete, but the estimated total of at least $£ 519$ millions includes $£ 11$ millions to China, $£ 106$ millions to France, $£ 228$ millions to Poland, $£ 34$ millions to Greece, $£ 30$ millions to Czechoslovakia, $£ 24$ millions to Belgium, £14 millions to Yugoslavia, and $£ 32$ millions to Turkey. These mutual aid arrangements have now ceased and trading is again on a cash basis. The vast flow of commodities and services exchanged and consumed in fighting the common enemy are not being left standing as monetary liabilities, but are being cancelled by common consent. This record of aid rendered by the United Kingdom provides a measure of an impressive aspect of her war effort which it is appropriate to recall at the present moment.
Health of University Students in Italy

The substance of an address delivered by Marc Daniels at a confeypeld held in Italy in connexion with the Xatiop Council of Research in 1945 has been publ Wed (Ric. Sci. e Ricostruz., March-April f46) $M$ He points out that university students are pypatially the most precious possession of a nation, because they represent the intellectual and professional leaders of the future; but they are susceptible to various maladies during their period of study. It is remarkable that in the past so little eare has been exercised on their behalf, not only in Italy but also in other countries. Daniels regards tuberculosis as the most serious problem confronting them because it is responsible for more deaths among the young people of both sexes than any other disease. During the War the mortality from tuberculosis increased considerably and in some parts of Italy was doubled, while in London it increased by 70 per cent among the young in the first year of the War. After tuberculosis, venereal disease assumed alarming proportions during the War in different countries, and there is no reason to think that Italy is an exception. A short description is given of the efforts that have been made to combat tuberculosis among students in the United States, Great Britain and France. The latter country has a special anti-tubercular service for university students, of which the author, who had first-hand knowledge of its working when it was initiated in 1932, speaks most highly. Although he does not think that in existing circumstances a national medical service in Italy is possible, he is convinced that every university in the country should regard the organisation of such a service for its students as lying within the limits of possibility. Medical attention at the beginning of a student's career and subsequent attention annually should form a chief part of the prophylactic services. Given a sufficient number of men of good will in the faculty of medicine, prepared to collaborate in the preparation of a medical programme, and given the cooperation of other faculties and also of students' organisations, the University of Rome should be able to institute a medical service for the students which would serve as a model for the assistance of the young people of Italy, on whom depends the future of the country.

\section{A Welsh Folk Museum: St. Fagans Castle}

A FULL descriptien the Earl of Plymouth's magnificent gift acres $0 \mathrm{f}$ ard, to the National Museum of Wales appears 1 the Museums Journal of September. Fфllowing this gift (which was made this year) Lord PIWuth has artanged, "on very acceptable terms", the transfer to the Museum of an extra 80 acres of the park-land adjoining the gardens. This additional acquisition was essential in view of the development of St. Fagans as a folk museum. The establishment of a Welsh Folk Museum as an extension of the National Museum's services has been a long-felt need. In 1943 the Welsh Reconstruction Advisory Council provided an opportunity for publicly pressing the adoption of the proposal, and upon this the Museum Council submitted a recommendation that an openair museum was an essential auxiliary to the National Museum of Wales. This recommendation was adopted by the Advisory Council, and now, in 1946, the scheme proposed materializes through the generosity of Lord Plymouth. 